\section{The perceptions of medical researchers on qualitative methodologies}

\author{
Percepção de pesquisadores médicos sobre \\ metodologias qualitativas
}

\section{Percepción de los investigadores médicos en metodologías cualitativas}

\author{
${ }^{1}$ Universidade do Estado do \\ Rio de Janeiro, Rio de Janeiro, \\ Brasil. \\ 2 Escola Nacional de Saúde \\ Pública Sergio Arouca, \\ Fundação Oswaldo Cruz, \\ Rio de Janeiro, Brasil. \\ Correspondence \\ S. R. Taquette \\ Universidade do Estado do \\ Rio de Janeiro. \\ Boulevard Vinte e Oito de \\ Setembro 109, Rio de Janeiro, \\ RJ 20551-030, Brasil. \\ stella.taquette@gmail.com
}

\begin{abstract}
We aimed to verify doctor's perception of the qualitative research method, via a qualitative study of interviews with questions on the academic profile of doctors and on the methodology. We interviewed 42 professionals, of which 18 had experience with the qualitative method and 24 with the quantitative method. The results showed that knowledge on the qualitative method was virtually nil among "quantitative researchers", who did not value qualitative research, although some of those realized that it would be important to be more accepting in clinical practice. Others only considered the method as subsidiary to quantitative. The majority considered qualitative methods as lacking academic structure, taking too long to conduct empirical studies, and being difficult to publish. All of them criticized the misuse of the method, and the "quantitatives" pointed out the problem of being unable to reproduce. We concluded that widening the use of the qualitative method by doctors requires investment from the beginning of the academic career and participation in qualitative research projects.
\end{abstract}

Physicians; Research Personnel; Qualitative Research
Stella Regina Taquette 1 Maria Cecília de Souza Minayo 2 Adriana de Oliveira Rodrigues 1

\section{Resumo}

Objetivamos verificar a percepção de médicos sobre o método qualitativo de pesquisa. Estudo qualitativo por meio de entrevistas com questões sobre o perfil acadêmico do médico e perguntas abertas a respeito do método. Entrevistamos 42 profissionais, sendo 18 com experiência no método qualitativo e 24 com o quantitativo. Os resultados evidenciaram que o conhecimento sobre o qualitativo é quase nulo entre os pesquisadores "quantitativistas", os quais não valorizam a pesquisa qualitativa, embora alguns percebam que seria importante ter uma postura mais compreensiva na prática clínica. Outros só a veem como subsidiária ao quantitativo. As principais dificuldades da maioria são: falta de formação, tempo longo despendido nos estudos empíricos e dificuldade de publicação. Todos os entrevistados criticaram o mau uso do método, e os "quantitativistas" ressaltaram, como problema, sua não reprodutibilidade. Concluímos que ampliar o uso do método qualitativo por médicos exige investimento na formação desde o início da graduação e participação em projetos de pesquisa qualitativa.

Médicos; Pesquisadores; Pesquisa Qualitativa 


\section{Introduction}

Research in health sciences is mostly developed through the use of quantitative methods, which can be defined as logical, experimental and mathematical. These methods have a tendency towards extensive phenomenon which means that they allow for objectivity and neutrality, and are hypothetico-deductive, replicable and generalizable 1 . Research which does not fall under the category of being quantitative is normally conducted by non-medical researchers and does not directly follow clinical practice. However, many health care issues need to undergo research using a comprehensive approach, which is not familiar to medical researchers who carry out their activities in direct contact with patients. We emphasize, therefore, the importance of quantitative and qualitative studies that contribute towards analysis and proposals for solutions in the field of health.

Qualitative research, according to Denzin \& Lincoln 2, is in itself, a field of research around which are terms and assumptions that are interconnected across disciplines and themes. This field can be considered as the embracing of different approaches used to describe, understand and interpret experiences, behaviors, interactions, and social contexts. Qualitative approaches in the field of health also encompass various theories and models of study such as: ethnography, case study, oral history and documentary analysis, among others ${ }^{3}$. In this study we have taken the concept of Minayo 4 according to whom qualitative research deals with a level of reality that is explored through: history, biographies, interactions, the meaning of the universe, explanations, aspirations, beliefs, values, attitudes and it embraces other techniques related to empirical work.

Scientific publications on qualitative research use the language of social sciences. This is unusual for doctors with technical training geared towards complex procedures required to deal with diverse pathologies. As a result, the few health care professionals who work with qualitative methods are criticized on the grounds of the superficial nature with which they address social reality. They are also criticized on the grounds of their inability to discuss empirical data and to apply theory in a consistent and thorough manner 5,6.

The principle focus of doctors is human beings whose existence is influenced by history, social relations and interactions between each other. Whether the body is healthy or not is dependent on sociocultural and emotional factors as noted by Fleck 7 , in the last century, referring to the im- portance of observing the weight of external factors on the individual, in the genesis of diseases.

Also Canguilhem ${ }^{8}$ notes, that it is clear that medicine is a science that is closely connected to cultures in general, therefore, any change in medical concepts is closely related to socialhistorical changes in society. Perhaps this is why Cassorla 9 argues that working with qualitative methods can provide better results than what can be given by clinical doctors. This is because the clinical doctor, in his office, needs to thoroughly understand his patient, and not just the signs and symptoms that are presented.

In consideration of the aforementioned, the question that is posed is how does one encourage qualitative methods in the field of health care? How can medical researchers be empowered to use other such approaches? We tried to answer these questions, interviewing medical researchers about their knowledge of qualitative methods, the values that can be attributed to this method, the difficulties in its implementation, and suggestions of how to expand their use.

\section{The methods used to carry out the research}

This study was carried out by means of a qualitative approach and the use of the hermeneutic dialectic method 4 , which saw the use of semistructured interviews carried out with medical doctorate researchers. The interviews allowed us, through what the interlocutors had to say, to better understand the social group's value system and its structural conditions, whilst at the same time it also allowed us to understand representatives from other groups which allowed us to take into account historical, socioeconomic and cultural factors ${ }^{4}$. Through the narratives of the interlocutors and taking into account the contexts in which they were given, we sought to critically understand their statements, not necessarily analyzing the truthfulness of their responses, but rather to understand their vision of reality 10 .

The sample was intentionally made up of two categories of researchers: those that use predominantly quantitative methods and those who work primarily with qualitative methods. We confirmed this through their Curriculum Lattes (http://lattes.cnpq.br) as well as checking on what research they had previously conducted.

We wanted to interview only medical researchers with clinical experience, whose qualitative studies were indexed in the SciELO Brazil over the last 10 years. Out of the 40 that we contacted (through sending repeated messages), only 12 agreed to participate. This lack of participation 
in the study in relation to the desired profile led us to include other medical researchers who did not have clinical backgrounds and/or did not use qualitative methods. Requests were sent to researchers from different institutions, graduate programs and those that specialized in certain areas. We interviewed 42 professionals, 18 of whom had greater experience in the use of qualitative methods and, 24 with experience of quantitative methods. To ensure the diversity of the sample, we conducted face-to-face interviews, as well as sending questionnaires through emails or conducting interviews via Skype.

The interviews followed a predefined format that had been previously tested, which covered demographic data, the respondent's educational background and professional experience. We also used open-ended questions concerning values, difficulties, the opinions of critics and barriers in respect of the use of qualitative methods for research. The inclusion criterion was essentially being a graduate in medicine or being a research doctor.

The interviews were conducted by three researchers, two of whom had a medical background and one was a social service worker. The majority of the respondents had no close relationship with the interviewers, avoiding any conflict of interest or ethical issues in the conduct of the study. We transcribed the interviews in their entirety, (with the exception of those conducted via e-mail). Thirty transcripts was equivalent to 17 hours of recordings. In relation to the twelve interviews conducted via e-mail, each on average produced, three pages of text. We followed closely all the information that was collected whilst at the same time following the manner in which it was collected. We also took great care in choosing our sample and we sought to ensure the replication in the use of our methods for all those in our sample.

We performed an analysis of data from the interviews conducted via email and the ones done face to face at the same time, because all followed the same script. We used the hermeneutic-dialectic method 4 , in that we sought to understand the discourse within the logic of the interviewees, putting it into critical perspective and analyzing the internal contradictions that permeated. In relation to the interpretation of the results, we relied on a collaboration of professionals from different areas, in an attempt to obtain an agreement from all parts and a mixture of points of view. We followed the following steps: reading and re-reading the reports to fully understand what the interviewees were saying and the relevance of what they had to say in relation to this report; cross classification of speech, creating analytical categories from the empirical catego- ries (knowledge, value to be attributed to qualitative approaches, criticisms given, difficulties/ barriers mentioned and suggestions for its use); identification of the meanings attributed by the subjects to the issues raised; analysis of internal contradictions within what was said in the interviews and in comparison with what was said later; comparison with associated literature; and, preparation of an interpretative synthesis.

The research complies with the ethical principles of the Declaration of Helsinki. It was approved by the Ethics Research Committee of Pedro Ernesto University Hospital, Rio de Janeiro State University, on December 12, 2012 (reference n. 155.405).

\section{Results and discussion}

In this part we will describe the profile of the respondents and then we will present the results through the following sub-themes: knowledge and value assigned to qualitative methods, difficulties, barriers and criticism of its use and suggestions to broaden and deepen the implementation of its use in the medical area. We also intend to highlight the differences and similarities in relation to the perceptions of the researchers.

The sample was composed of $50 \%$ professional males and $50 \%$ professional females. The female respondents were more prevalent in the group made up of qualitative researchers and the men, amongst the quantitative researchers. Those that were aged 50 or over represented $74 \%$ (31) of the respondents, $19 \%$ (8) were aged between 41 and 50 years old and only $7 \%$ (3) fell within the age range of 33 to 40 years old. The average time taken by the respondents to complete their doctorate was 12.5 years, and $28.5 \%$ were scholarship researchers in the area of productivity at the Brazilian National Research Council (CNPq). All of them were attending institutions of higher education located in either São Paulo [which was one of the following institutions: São Paulo University (USP), Federal University of São Paulo (UFSCar), Federal University of São Paulo (UNIFESP), Campinas State University (UNICAMP) and Anhembi Morumbi University (UAM)], Rio de Janeiro [which was one of the following: Rio de Janeiro State University (UERJ), Federal University of Rio de Janeiro (UFRJ), Oswaldo Cruz Foundation (Fiocruz)], Minas Gerais [Federal University of Minas Gerais (UFMG)] and Santa Catarina [Contestado University (UnC)]. Their specialist fields were varied, with public health and psychiatry being the most common areas.

The 24 respondents who primarily used quantitative methods had similar profiles to the 
rest of the sample with respect to their academic background. However, in this group there were predominantly those who practiced in specialist clinical areas (16) such as: clinical medicine, pulmonology, cardiology, family medicine, pediatrics and psychiatry among others. The others practiced in the following areas: epidemiology (4) and specialisms in specific surgical practices, general surgery, gynecology/obstetrics and otorhinolaryngology (4). The motivation of the members of this group to act as researchers varied between curiosity, an interest in producing knowledge in order to tackle problems or the necessity based on their chosen profession in teaching.

The 18 interviewees with experience in the use of qualitative methods predominantly represented researchers in public health (9) and, in psychiatry (3). The others represented the following areas: gynecology and obstetrics, clinical medicine, pediatrics, family medicine and homeopathy. The motivation behind the pursuit of a career as a researcher centered around: scientific curiosity, pleasure in learning and producing useful knowledge.

\section{Knowledge and value assigned to qualitative methods}

Knowledge of qualitative methods from a large section of the interviewees who worked with quantitative methods was small. They stated that this was due to there being a lack of training and also difficulties in the understanding of certain concepts. Some said they had participated in classes covering this method of research at postgraduate level without having understood the complexities of the logic underlying the qualitative studies. However, we observed that this universe is not homogeneous: in other words a lack of understanding generated disinterest in some and a desire to learn in others.

"I am not totally au fait with qualitative methods. I find it difficult to understand".

"My knowledge of qualitative methods is zero. I would like to learn more. I did a PG but this didn't help at all".

Some researchers claimed to have a good working knowledge in this area, although it was outdated as it had been based on experiences in graduate school. They said that they had been trained in the human sciences, had a personal interest in the area and had been influenced by their family. Others expressed disregard for this type of research method, offering up criticisms that were erroneous, and expressing dogmatic attitudes in relation to the use of this research method 11. For the latter, the qualitative resear- chers were "journalists" or scientists of soft sciences whose work is not scientific and only serves to give a broad overview of particular area 2 .

"Qualitative methods have received wide criticism in relation to its subjectivity. The need for reproducibility is fundamental for scientific rigor".

However, the recognition of the value of the qualitative method was expressed by some of the respondents. They emphasized the point that it is one thing to conduct research in laboratories and controlled environments, while it is something else to conduct research with real life patients who have complexities base on their biological, physical, psychic and spiritual makeup.

"The subjective impressions that a person has doesn't always appear as objective data. We cannot devalue what people say about their own suffering".

"There are subtleties for each patient in relation to taking their medication based on the hours it is taken, whether they follow what is required or if they mix it with other medication. Therefore it is no wonder that several drugs that proved to be extremely effective in clinical trials, once place in the open market fail to produce the desired results".

Others said they considered the qualitative methods important, but only as ancillary or complementary to quantitative studies. This vision reflects the low value given to qualitative methods in the medical area, whose prevalence is mainly in the area of epidemiological studies. This area also receives the greatest amount of funding from agencies to conduct this type of research. In other words, the scientific disputes in this area express themselves as much in the debates surrounding concepts and appropriate methodologies, as in the politics and economics that also pervade this area 12 .

In spite of the directions given in the national syllabus for medicine which takes a generalist, humanistic, critical and reflective 13 approach, the majority of the medical schools in the country are influenced by the Flexnerian model used in the teaching of medical specialists. In this model, there is a separation between the basic sciences and clinical disciplines are divided into departments. The hospital is the main field of training and the development of research follows the methods used in basic sciences 14 . In other words, medical courses do not give priority to issues involving human life in its fullness. Trained doctors are technically prepared to treat diseases, including those of high complexity, but they have difficulty in looking at the patient within historical, social, psychological and biological contexts and systems in which they live. This type of training is a barrier to the understanding of qualitative studies on 
health that require interaction between people and contextualization of the problems.

The group of researchers who worked with qualitative methods all claimed to understand the different approaches. Most had solid training and experience in conducting research, guiding students and post-graduate teaching. Some had stressed that they had acquired their skills in relation to this method through using it in practice and not through academic training. Others considered that the training that they had received in qualitative research wasn't good.

The qualitative researchers attached great value to the methods they used with some strongly arguing in favor of formal training, within a medical context and having a critical perspective. This is because a greater part of the interactions with patients is qualitative. For this reason, they were of the view that only through the use of this type of research method can one elucidate the subjective and cultural dimensions involved in searching and accessing health care. Other respondents put emphasis on its auxiliary role allowing it to complement quantitative methods and reinforce statistical data. Also others respondents highlighted the fact that the qualitative research is necessary in all kinds of research, be it quantitative or qualitative, because any results gleaned from the study would eventually need to be analyzed.

"I think that everything that relates to the discussion of results that were found in the research process requires a qualitative perspective: the results are just the tip of the iceberg".

The perception of the need to start looking at qualitative methods in the area of health care was highlighted in an editorial from the journal Health Services Research 15. According to Shortell 15, qualitative methods have played increasingly important roles in research on health services and this reflects the need for a deeper understanding of the lives of patients which will help in implementing necessary changes.

\section{Difficulties and barriers in the use of the method}

Some of the barriers highlighted included: the training of physicians, the presence of the researcher and their interactions with the subjects of the research in field work, the difficulties to publish research findings, the issues of subjectivity that can give rise to biases, the difficulty of researchers to distance themselves from what they are investigating and allowing their opinions to cloud their understanding of the data collected in the field.
Concerning medical training, much has been talked about in this area, particularly on the lack of content in the area of human sciences. This lack of content makes learning difficult in relation to social, psychological and philosophical themes according to reports produced by quantitative researchers themselves. What was made evident was that doctors didn't necessarily dislike the inter-subjectivity inherent in this method but they felt this area sat outside of their area of expertise, making it difficult to grasp the essence of any research conducted. However studies based on statistical data were considered synonymous with all things scientific. They thought it difficult to think outside of the area of logic which had formed the basis of their training. The lack of understanding due to lack of training leads to an adverse view of qualitative methods, resulting in them being considered of low value and unscientific.

"In the scientific world great value is given to areas that are quantitative and measurable according to Galileo".

"Not everyone is trained to do this nor do they have any preparation to conduct this type of research from their training institutions. Because of this people are unbelievers in their own capacity to produce knowledge in this way".

"We don't have any education in the area of human sciences. You need to look carefully to understand that everything has a history, correlations, cultural values that compete on different levels".

The amount of time spent conducting the research and doing the analysis isn't of great value for qualitative research. On the other hand quantitative studies, for example, can take years to be completed. The majority of qualitative research requires: the physical presence of the researcher in the given field of work, multiple readings of textual data and the ability to understand inherent meanings behind what a person states whilst they are the subject of any research.

The involvement of both the researcher and the researched, which is a characteristic of the qualitative approach, was noted as possibly presenting problems for example where certain sensitive themes are touched on such as pain, suffering and death. In this case, the researcher isn't merely an external actor watching what happens, but is a human being that shares in the feelings, experiences and emotions of the groups that are being studied ${ }^{16}$. It is ethically important that the researcher takes into account any influence that he may have on the results of the research. The criteria for assessing the quality of a study is closely contacted to the ethical standards of research 17 . In his reflections, Geertz 18 draws at- 
tention to the ethical dimensions of field work and the difficulties inherent in this process, since in one sense the researcher is an actor involved in the study yet at the same time he needs to be an impartial observer.

The difficulty of publishing scientific articles that use qualitative approaches in the area of health deserves special consideration. The interviewees pointed out that there is a small body of work in relation to this method in the world of health studies and research. Where there are published studies that have used this method of research, they are often discounted as being nonscientific lacking due rigor in the collection and analysis of the information and just being akin to interesting stories given by people 19 .

In other words, the way in which research is conducted will have a bearing on whether it is considered and published as scientific. Despite there being an increase in the publication in major international medical journals of qualitative research over the past 10 years, the percentage is still very small. Journals with editorial policies that include the publication of qualitative studies, publish more research of this nature and there is a recent recognition of the value of this type of approach by some journals such as the Lancet and Journal of the American Medical Association. However, the empirical evidence is that articles with qualitative research hardly ever receive publication exposure in the majority of important journals. In the last 10 years, there was a 3.4 fold increase in the number of qualitative studies that were published internationally $(1.2 \%$ in 1998 and $4.1 \%$ in 2007) 20.

Studies have shown that there is sparse representation of these types of studies in the area of health care. Searches that looked at articles published in 170 major medical journals in 2000 showed that out of 60,330 articles that were published, $355(0.5 \%)$ were qualitative research. All of those articles had been published in 48 different journals. The majority of the articles covered the area of nursing. Only four studies had been published in important and renowned journals 21 . Another study that was conducted looking at articles relating to health services and management, where all of these articles had been published in nine major international journals over a period of three years (1995 to 1997), showed that only one in every seven used qualitative research 22 . Yamazaki et al. 23 reviewed articles published between 2000 and 2004 in general medical journals of note such as: British Medical Journal, Lancet, Journal of the American Medical Association, Annals of Internal Medicine and the New England Journal of Medicine. Of these, only $11 \%$ were based on qualitative studies. According to
Meneghini 24, coordinator of SciELO in Brazil, in recent years there has been a large increase in the amount of work being carried out in Brazil in the area of health sciences. This has resulted in Brazil occupying third place in the worldwide in 2008, being surpassed only by the United States and England. Despite this large increase which also includes the publications of research in the field of public health 25 , qualitative studies do not feature highly in these studies. For this reason, according to Morse 26 who is the editor of the journal Qualitative Health Research, qualitative research is still on the fringes of science. In his opinion, doctors persist in the belief that such methods are subject to bias, not replicable, they are devoid of presentable and cogent evidence, and thus are unacceptable.

Finally, some researchers who use qualitative methods are plagued by their own internal uncertainties concerning their approach which has be propagated by quantitative researcher. They often feel the need to justify their chose in the use of this method to their peers. Others dispense with some specific aspects of qualitative research with a view to imitating aspects of quantitative research, as you can see from the following quotes.

"We need to find a way of apologizing for using qualitative methods, so we spend half of the article justifying why we used it".

"I'm chocked to how people from the qualitative disciples look to imitate quantitative researchers. For example, they published an article based on the life history of six authors. I can't see any justification for this. The frenetic production of this type of work creates a series of perverse incentives that are actually enemies of science".

\section{Criticism of the use of qualitative methods}

The most frequent criticism emphasized by interviewees who work with quantitative methods is not qualitative methods in themselves, but the poor use of them. They cited examples such as: leading questions, interpretations of results which is common sense and a lack of sociological knowledge, particularly in the preparation of analysis. However, such problems are not exclusive to qualitative research. These criticisms can be found all research fields and methods.

Many also questioned the subjectivity involved in empirical approaches, the lack of scientific rigor, the inability to generalize the results and, therefore, its reproducibility. Some have stressed that the theoretical, methodological and operational weakness that they have observed in many works give rise to criticism, because it shows a lack rigor and can result in the production of 
research of poor quality 27 . On the same vein criticisms have been levied on the social scientist due to the generic interpretations that they come up with which are often completed disconnected from the practical problems that affect the health of the population:

"The text readily turns into the personal opinion of the researcher which isn't qualitative research".

"They often say I think this or I think that as a pure description of a simple event. They don't do analysis in the way that it should be done. For this reason the study is often discredited".

"Brazilian research [by social scientists] is extremely biased in favor of generic systems that have no connections to specific problems. The guy studies the patient and then switches to speaking in a way that is both capitalistic and western in outlook".

The criticism of social scientists is corroborated by Cano 28, who is himself a social scientist and professor with extensive experience in the teaching of research methodologies. The author emphasizes that Brazilian social sciences favor theory at the expense of research, promoting erudite knowledge more than the technical aspects associated with research. Well conducted qualitative study must be based on extensive and comprehensive literature reviews that provide a conceptually solid structural basis for an analysis of the given theme. It must also: give a clear description of the data collected in the field of inter-subjectivity, include comprehensive analysis and criticism of the facts, produces an interpretation that challenges national and international works in their field and have the ability to transform its findings into concrete proposals that can be used, as stated by Marx. But at the heart of the study must always be the defined objective of the research.

The respondents in the qualitative area also questioned the poor use of methods: inadequate use of the research methods, the simplification of the commentaries given, the lack of deep theoretical and methodological analysis and gaps in the level of understanding and interpreting of the results. They were unanimous in their belief that the published studies often do not express the methodological path in a convincing manner, so as to generate reader confidence when a conclusion is presented.

"If you do not express with rigor the methodology used, in other words what you actually did, and how to interpret what you did, the conclusions that you come up with will be considered weak".

The qualitative researchers, in accordance with required standards, considered that trans- parency in the demonstration of the research process was a requirement for the quality of the research. They stated that the plethora of details concerning the procedures adopted generates more credibility about the results 29 . According to Fossey et al. 17, in relation to the description of the research, what's been discovered and your analysis, all of these needs to be based on empirical evidence sufficient to allow a third party to determine the applicability of the results for their own given circumstances.

Although there is criticism of the two groups of researchers on the use of qualitative methods, they differed in their content. The criticisms given by qualitative researchers were more detailed, based on fact and were well-founded. They highlighted the most frequent errors committed by those who use this methodology. On the other hand quantitative researchers spoke of the principles that govern logical positivist science. Yet a few recognized that they didn't have a full grasp of the basics that underlined this research method nor practical experience, despite criticizing it.

The same positivist logic can be seen in the evaluation models from the qualitative articles. These rules have been imported from the quantitative discipline. There aren't many journals that allow more than 3 to 5 thousand words, which can hinder the submission of well prepared studies 30 . Recognizing this inadequacy, Barbour \& Barbour 31 advocates a model of evaluation more appropriate to the specific characteristics of the qualitative method. The author emphasizes that it is important to recognize the differences between the methods, also the norms in relation to publication and the evaluation of the studies. Mori \& Nakayama 32 adds that, for a proper evaluation of qualitative studies in the area of health, it is necessary to develop a framework that includes discussions of clinical implications of scientific discoveries.

\section{Suggestions for the expansion of education} and the use of qualitative methods

The quantitative researchers stated that the main factor for the teaching of qualitative method and for the expansion of its use in the area of medicine is evidence of its usefulness in practice. Another important suggestion is making learning less theoretical and more practical. In other words, teach the methods of conducting research in a dynamic way, using techniques that stimulate the students in the various environments in which this is possible. To increase the use of qualitative approaches, several interviewees suggested some initiatives: seek the support of qualitative 
researchers that are competent to advise clinical research groups; conduct interdisciplinary studies that bring together the areas of social sciences, the humanities and medical disciplines; and disseminating the results of qualitative research in congresses, in the classroom, in universities and in different medical environments.

"In reality, in the area of qualitative research we don't see much weight being placed on its value. Therefore there should be a way to reverse this. At the beginning [this is the area I did whilst doing my postgrad] I thought it wasn't worth doing, but then I realized that it was".

The inclusion of disciplines from the humanities in undergraduate and post-graduate studies was noted as essential to increase the knowledge of methods and on the structural concepts of qualitative research. This would in turn increase the competences required to use the methods with rigor. The construction of scientific knowledge in human sciences is constituted through the acts of listening, looking and writing, the sum of which is interpreted through analysis of the data and then it is articulated in a prescribed form ${ }^{33}$. The resultant scientific report seeks to understand and interpret the internal logic and to elaborate on the results. The final report is therefore based on what has been found, empirical data and existing universal knowledge 34,35 .

Some authors argue that the knowledge of social theory is as important for high quality qualitative research as statistical knowledge, for conducting good epidemiological studies. In reality, in spite of social scientists taking a lot of care in limiting their conclusions to the universe of research, lot of work which has extrapolated micro-social conclusions have been taken out of the academic world to be used in other areas 36 .

It was almost unanimous amongst the qualitative researchers that there is a need to improve training in medical human sciences which includes the philosophy and social sciences syllabus. This is because working with qualitative methods requires better knowledge in these areas. They all also agreed that, in general, students do not have much interest in the methodological theory used in both qualitative and quantitative research. They argued that emphases should be placed on practical teaching using the methods in research projects and providing presentations using simple examples in medical care. It is hoped that an increase in human science content at undergraduate level will greatly contribute towards doctor's training.

According to Turato ${ }^{19}$, doctors are in a very good position in identifying and better understanding the problems with qualitative research because they have close contact with the subjects of the research and because of their experience. However, the level of closeness required wasn't given. Nevertheless this closeness needs to be built up and planed with a specific strategy which allows for greater understanding and an analysis of the situation 37 .

Upon considering the need to use qualitative methods in health care to tackle medical problems, what was brought to our attention was the teaching and learning methods of Calderón 38 , a family doctor from the Center of Primary Care in San Sebastián, Spain. In agreement with what had been said, Calderón 38 says that health care work has a complexity for which there is a need for a qualitative approach, because the following issues are often touched on such as: values, beliefs, points of views, attitudes and behaviors concerning health and diseases. But there needs to a working partnership between the social sciences, the humanities and medicine. Social scientists must be in a position to translate the language and methods used in social sciences in an understandable manner for the benefit of health professionals 39 .

Finally, it was stressed by the interlocutors, the importance of not negatively comparing qualitative and quantitative research. In "mathematics transcendental" Kant 40 said that every object has an extensiveness that can be counted and an intensity that needs to be understood. Cano 28 and Minayo 4 argue that the separation between quantitative methods and qualitative methods is artificial. The quantification or apparent difficulties in measurements is only external in nature, and is secondary to any study. The epistemological dilemmas faced by ethnographer or by the professional who works with surveys are the same. All scientific evidence, quantitative or qualitative must be evaluated with care to offer valid conclusions.

\section{Some considerations}

A number of points need to be highlighted in concluding this report. Firstly, it is important that investment is made in medical training for future professionals so that they are able to use both quantitative and qualitative research and so that they can become competent in the development of research into relevant health issues. According to the interlocutors, the prevailing concept which dominates medical teaching is that of a positivist view of science where health and disease are considered biological phenomena. Under this view a lot of weight is placed on technology coupled with the absolute belief that medicine has the power to eradicate diseases at the detriment of 
considering and analyzing the population from a qualitative perspective 4 . It should also be noted that epistemological problems exist in the area of health care studies, independent of whether the study is conducted using quantitative or qualitative methods and normally this will become evident during the course of the research.

Secondly, we considered it important to increase the use of qualitative studies and in turn their publication in both national and international journals. For this reason it is important that funding providers, editors and reviewers are convinced of the benefits of this type of research with particular focus on the specifics of the research and for whom the research will benefit. Such measures will help to improve the quality of these studies.

Thirdly, authors such as Weiner et al. 41 suggests that the teaching of qualitative methods should be mandatory for all doctorate programs even where the students have no intention of utilizing them in the future. It is thought that a greater understanding of this type of research will produce added value when empirical research is conducted and the researcher will have a greater ability to evaluate the quality of scientific studies. It also should be noted that another reason why these students should be trained in this area is that they may become future editors and reviewers of the very same medical journals which should publish these types of studies.

Finally, we also recognized the limits of our study. The research which gave rise to this article focused on the role of only one professional in the chain of production of health care knowledge, namely the doctor. Another limitation of the study concerns its territorial coverage. However, it hoped that we have presented, described and analyzed the most important elements and protagonists in the development of this type of health research. We also sought to highlight the great responsibility placed on all those that are involved in this area as well as showing the hegemony of their ideas and their actions in their professional environment. 


\section{Resumen}

El objetivo es verificar la percepción de médicos sobre el método de investigación cualitativa. Se trata de un estudio cualitativo por medio de entrevistas con preguntas sobre el perfil de los médicos y sobre el método. Entrevistamos a 42 profesionales, 18 con experiencia en el método cualitativo y 24 con el cuantitativo. Los resultados mostraron que el conocimiento sobre lo cualitativo es casi nulo entre los "cuantitativistas", que no valoran la investigación cualitativa, aunque algunos se dan cuenta de que sería importante tener un enfoque más amplio en la práctica clínica. Otros la ven como subsidiaria a lo cuantitativo. Sus dificultades para utilizar ese abordaje son: falta de formación, cantidad de tiempo que exigen y problemas de publicación. Todos han criticado el mal uso del método. Los "cuantitativistas" han destacado como fragilidad, la no reproductibilidad. Llegamos a la conclusión de que para ampliar el uso de los abordajes cualitativos entre los médicos es importante invertir en su formación desde el inicio del curso y la participación en proyectos de investigación cualitativa.

Médicos; Investigadores; Investigación Cualitativa

\section{Contributors}

S. R. Taquette participated in the design of the study, collection, analysis and interpretation of data and preparation of the manuscript. M. C. S. Minayo collaborated in the design of the study, analysis and interpretation of data and preparation of the manuscript. A. O. Rodrigues contributed to the data collection and analysis and final review of the manuscript.

\section{Acknowledgments}

The authors are grateful to fellow doctors, research subjects of this study; the scientific initiation scholarship of FAPERJ Antonia Catherine Correia Viana and FAPERJ for the financial support.

\section{References}

1. Demo P. Ciências sociais e quantidade. In: Demo P, organizador. Ciências sociais e qualidade. São Paulo: Almed; 1985. p. 7-22.

2. Denzin NK, Lincoln YS. Introdução: a disciplina e a prática da pesquisa qualitativa. In: Denzin NK, Lincoln YS, organizadores. O planejamento da pesquisa qualitativa: teorias e abordagens. $2^{\text {a }} \mathrm{Ed}$. Porto Alegre: Editora Artmed; 2010. p. 15-42.

3. Victora CG, Kanuth DR, Hassen MNA. Pesquisa qualitativa em saúde. Uma introdução ao tema. Porto Alegre: Tomo Editorial; 2000.

4. Minayo MCS. O desafio do conhecimento: pesquisa qualitativa em saúde. 13a Ed. São Paulo: Editora Hucitec; 2013

5. Canesqui AM. Sobre a presença das ciências sociais e humanas na saúde pública. Saúde Soc 2011; 20:16-21.

6. Gomes MHA, Silveira C. Sobre o uso de métodos qualitativos em saúde coletiva, ou a falta que faz uma teoria. Rev Saúde Pública 2012; 46:160-5.
7. Fleck L. Gênese de desenvolvimento de um fato científico. Belo Horizonte: Editora Fabrefactum; 2010.

8. Canguilhem G. O normal e o patológico. $2^{\text {a }}$ Ed. Rio de Janeiro: Forense Universitária; 1982.

9. Cassorla RMS. Prefácio. In: Turato ER, organizador. Tratado da metodologia da pesquisa clínico-qualitativa: construção teórico-epistemológica, discussão comparada e aplicação nas áreas da saúde e humanas. Petrópolis: Editora Vozes; 2003. p. 19-32.

10. Rabelo MC. Experiência de doença e narrativa. Rio de Janeiro: Editora Fiocruz; 1999.

11. Moser PK, Mulder DH, Trout JD. A teoria do conhecimento: uma introdução temática. 2a Ed. São Paulo: Editora Martins Fontes; 2009.

12. Bosi MLM. Pesquisa qualitativa em saúde coletiva: panorama e desafios. Ciênc Saúde Coletiva 2012; 17:575-86. 
13. Câmara de Educação Superior, Conselho Nacional de Educação. Resolução CNE/CES n. 4, de 7 de novembro de 2001. Institui diretrizes curriculares nacionais do curso de graduação em medicina. http://portal.mec.gov.br/cne/arquivos/pdf/ CES04.pdf (accessed on 01/Jun/2014).

14. Almeida MJ. Educação médica e saúde: possibilidades de mudança. Londrina: EDUEL; 1999.

15. Shortell SM. The emergence of qualitative methods in health services research. Health Serv Res 1999; 34(5 Pt 2):1083-90.

16. Minayo MCS, Guerriero ICZ. Reflexividade como éthos da pesquisa qualitativa. Ciênc Saúde Coletiva $2014 ; 19: 1103-12$.

17. Fossey E, Harvey C, McDermott F, Davidson L. Understanding and evaluating a qualitative research. Aust N Z J Psychiatry 2002; 36:717-32.

18. Geertz C. O pensamento como ato moral: dimensões éticas do trabalho de campo antropológico em países novos. In: Geertz C, organizador. Nova luz sobre a antropologia. Rio de Janeiro: Jorge Zahar; 2001. p. 30-46.

19. Turato ER. Métodos qualitativos e quantitativos na área da saúde: definições, diferenças e seus objetos de pesquisa. Rev Saúde Pública 2005; 39:507-14.

20. Shuval K, Harker K, Roudsari B, Groce EM, Mills B, Siddiqi $Z$, et al. Is qualitative research second class science? A quantitative longitudinal examination of qualitative research in medical journals. PLoS One 2011; 6:e16937.

21. McKibbon KA, Gadd CS. A quantitative analysis of qualitative studies in clinical journals for the 2000 year. BMC Med Inform Decis Mak 2004; 4:11.

22. Hoff TJ, Witt LC. Exploring the use of qualitative methods in published health services and management research. Med Care Res Rev 2000; 57:139-60.

23. Yamazaki H, Slingsby BT, Takahashi M, Hayashi Y, Sugimori H, Nakayama T. Characteristics of qualitative studies in influential journals of general medicine: a critical review. BioSci Trends 2009; 3:202-9.

24. Meneghini R. Visibilidade internacional da produção brasileira em saúde coletiva. Cad Saúde Pública 2010; 26:1058-9.

25. Minayo MCS. A produção de conhecimento na interface entre as ciências sociais e humanas e a saúde coletiva. Saúde Soc 2013; 22:21-31.

26. Morse JM. Reconceptualizing qualitative evidence. Qual Health Res 2006; 16:415-22.

27. Daly J, Willis K, Small R, Green J, Welch N, Kealy $\mathrm{M}$, et al. A hierarchy of evidence for assessing qualitative health research. J Clin Epidemiol 2007; 60:43-9.
28. Cano I. Nas trincheiras do método: o ensino da metodologia das ciências sociais no Brasil. Sociologias 2012; 14:94-119.

29. Campos RO. Fale com eles! O trabalho interpretativo e a produção de consenso na pesquisa qualitativa em saúde: inovações a partir de desenhos participativos. Physis (Rio J.) 2011; 21:1269-86.

30. Dahlberg K. The publication of qualitative research findings. Qual Health Res 2006; 16:444-6.

31. Barbour RS, Barbour M. Evaluating and synthesizing qualitative research: the need to develop a distinctive approach. J Eval Clin Pract 2003; 9:179-86.

32. Mori I, Nakayama T. Academic impact of qualitative studies in healthcare: bibliometric analysis. PLoS One 2013; 8:e57371.

33. Oliveira RC. O trabalho do antropólogo: olhar, ouvir, escrever. Rev Antropol (São Paulo) 1996; 9:13-37.

34. Minayo MCS. Los conceptos estructurantes de la investigación cualitativa. Salud Colect 2010; 6:251-61.

35. Minayo MCS. Análise qualitativa: teoria, passos e fidedignidade. Ciênc Saúde Coletiva 2012 17:621-6.

36. Willis K, Daly J, Kealy M, Small R, Koutroulis G, Green J, et al. The essential role of social theory in qualitative public health research. Aust N Z J Public Health 2007; 31:438-43.

37. Baxter S, Killoran A, Kelly MP, Goyder E. Synthesizing diverse evidence: the use of primary qualitative data analysis methods and logic models in public health reviews. Public Health 2010; 124:99-106.

38. Calderón C. La enseñanza-aprendizaje de la investigación cualitativa en el medio sanitario. Ciênc Saúde Coletiva 2012; 17:595-602.

39. Marsiglia EMG. Temas emergentes em ciências sociais e saúde pública/coletiva: a produção do conhecimento na sua interface. Saúde Soc 2013; 22:32-43.

40. Kant I. Kant: coleção pensadores. São Paulo: Editora Abril; 1980

41. Weiner BJ, Amick HR, Lund JL, Lee SY, Hoff TJ. Use of qualitative methods in published health services and management research: a 10-year review. Med Care Res Rev 2011; 68:3-33.

Submitted on $17 /$ Jun/2014

Final version resubmitted on 10/Nov/2014

Approved on 01/Dec/2014 